Discussion Paper Series A No.697

Socioeconomic Status and Housework:

Cultural Differences in Participation in Routine Housework

in Japan, Canada, and the US

\author{
Kamila Kolpashnikova \\ (University of Oxford) \\ Ryota Chiba \\ (National Statistics Center) \\ and \\ Kiyomi Shirakawa \\ (Hitotsubashi University)
}

July 2019

Institute of Economic Research

Hitotsubashi University

Kunitachi, Tokyo, 186-8603 Japan 


\title{
Socioeconomic Status and Housework: Cultural Differences in Participation in Routine Housework in Japan, Canada, and the US
}

\author{
Kamila Kolpashnikova, University of Oxford \\ Ryota Chiba, National Statistics Center \\ Kiyomi Shirakawa, Hitotsubashi University
}

\begin{abstract}
The assumption about socioeconomic status (SES) and participation in housework are based on the empirical results in Western countries. As such, SES is assumed to work in a similar way in other regions as it does in the countries of the global north. This assumption can often lead to misguided interpretations of the effects of SES on housework participation in other cultural contexts. One such exception is Japan. We analyze time-use diaries from the American Time Use Survey for the period from 2003 to 2016, 1986-2010 Canadian General Social Survey, and the 2006 Japan Survey on Time Use and Leisure Activities (社会生活基 本調査). Using the negative binomial regression, we test whether SES is associated with less time spent on housework as the outsourcing hypothesis predicts. The findings show that this hypothesis stands only for Canadian and American women, whereas married Japanese women are unlikely to reduce their participation in housework with the increase of their SES.
\end{abstract}

Keywords: gender and housework, Japanese housework participation, Japanese time use, marital status gap, routine housework

\section{Introduction}

Do we live in an egalitarian society where women and men share housework equally? The literature on housework provides us with two main approaches to answering the question. The recent decades were dominated by the view that the gender revolution has been stalled (Hochschild \& Machung, 1989) and that we have not reached gender equality. However, even though full equality in terms of sharing housework has not yet been attained, to some extent the glass is half-full, as the other, more optimistic, side argues (Gimenez- 
Nadal \& Sevilla, 2012; Guppy, Sakumoto, \& Wilkes, 2019; Kan, Sullivan, \& Gershuny, 2011; Kolpashnikova, 2016, 2018).

Women today are no longer held to the standards of the traditional gender segregated division of household labor. For instance, the new generations are usually socialized in ways that promote more egalitarian gender scripts compared to older generations (Alwin \& McCammon, 2004). Baby busters hold more egalitarian beliefs in terms of gender norms than do baby boomers (Bianchi, Robinson, \& Milkie, 2006). Today men become increasingly involved in domestic chores. Marshall (2011) finds that Generation Y men spend, on average, 17 minutes more on housework than men from the late baby boomers generation. Similarly, an array of recent studies demonstrate that women devote less time to housework and that men gradually take on more responsibility in the United States (Coltrane, 2000) and in other countries, including the European Union (Gimenez-Nadal \& Sevilla, 2012; Kan et al., 2011) and Canada (Kolpashnikova, 2016; Marshall, 1986, 2011).

The analysis of the factors explaining the gender differences in housework, however, oftentimes assumes that the factors work similarly in many if not all cultural contexts. In this paper, we investigate whether socioeconomic status (SES) can predict the patterns of participation in domestic labor in Japan, as well as in Canada and the US.

The purpose of this project is to examine the factors that account for the gender and marital status differences in the allocation of time to household labor among Japanese, American, and Canadian women and men of different SES. The study will address two principal research questions (1) What are the patterns of participation in housework by 
gender and marital status depending on the socioeconomic status (2) Are the patterns similar among Japanese, American, and Canadian women and men?

According to the resource-based frameworks within housework theory (the relativeresources, the absolute-resources, and the time availability), the expectation for the housework performance among women and men of higher SES is that they will spend less time on it than women and men of lower SES.

Main Hypothesis (Hypothesis 1): The higher the socioeconomic status, the less routine housework is performed, regardless of gender, marital status, or country context.

\section{Methods}

For the Japanese data, we employed the anonymized microfiles of the 2006 Survey on Time Use and Leisure Activities (STULA). The STULA collects time diaries for two consecutive days. For the American data, we use the American Time Use Survey (ATUS), 2003-2016 (Bureau of Labor Statistics, 2018; Hofferth, Flood, \& Sobek, 2016). For the Canadian data, the microfiles of the Canadian General Social Survey (GSS) (Statistics Canada, 2011) were used for the following cycles: cycles 2 (1986), 7 (1992), 12 (1998), 19 (2005), and 24 (2010).

\subsection{Sample Selection}

The sample was chosen in a number of steps. There are four main subsamples within models: married women, married men, non-married women, and non-married men. Table 1 provides the overall descriptive statistics for the main dependent variable (housework time) among women and men in the three countries. The highest gender gap between average time 
spent on housework is in Japan (137 minutes, or more than 2 hours a day). Personal weights were re-coded based on the original survey weights and scaled to the original sample size.

Table 1 Dependent Variable: Descriptive statistics in Japan, the US, and Canada

\begin{tabular}{lccccc}
\hline & $\begin{array}{c}\text { Mean } \\
\text { (Women) }\end{array}$ & SE & $\begin{array}{c}\text { Mean } \\
\text { (Men) }\end{array}$ & SE & $\begin{array}{c}\text { Diff. in } \\
\text { Means }\end{array}$ \\
\hline $\begin{array}{l}\text { Housework } \\
\text { Japan }\end{array}$ & 154.099 & $(0.717)$ & 16.825 & $(0.238)$ & $137.274^{* * *}$ \\
USA & 104.639 & $(0.514)$ & 40.424 & $(0.360)$ & $64.215^{* * *}$ \\
Canada & 121.742 & $(0.815)$ & 42.933 & $(0.524)$ & $78.809^{* * *}$ \\
\hline${ }^{*} p<0.05,{ }^{* *} p<0.01,{ }^{* * *} p<0.001$ (adjusted Wald test) & & &
\end{tabular}

\subsection{Measures}

\subsubsection{Dependent Variables}

The dependent variable is represented by an aggregate measure of the time spent on indoor housework, mainly cooking and cleaning. We excluded shopping and services activities from the housework time because there are great differences in how people shop in Japan compared to the two North American countries.

Table 1 presents descriptive statistics for housework time between women and men in Japan, the US and Canada. There is a significant difference between time spent by women and that by men for all countries. On an average day, American women spend 104.6 minutes on cooking and cleaning, whereas men spend only 40.4. The gender gap in housework is higher in Canada than in the US and even higher in Japan, where it reaches 137.3 minutes.

\subsubsection{Independent and Control Variables}

The main independent variable - household income - is measured in ten million JPY in Japan, in hundred thousand USD in the US, and in hundred thousand CAD in Canada. The 
higher the household income, the higher the economic class of the family. We chose to use household income instead of personal income as the main independent variable for two reasons. First, household income is a better measure of SES, especially among women in Japan. Second, personal income information was not collected in the STULA in 2006.

The interaction dummy variables are the self-reported gender of the respondent (1= 'woman', $0=$ 'man') and whether the respondent is married ( $1=$ 'married', $0=$ 'otherwise'). In the US and Canada, the 'married' category also includes common-law partnerships.

Additionally, we control for the presence of children and education and age in years. Because the effects of age are often non-linear, we add also the quadratic term of age variable into models.

Time use researchers report that there are usually considerable differences in diaries depending on the day of the week the diary was collected on (Hook, 2017), we also control for whether the diary day was completed for a weekday ( $1=$ 'weekday', 0 = 'weekend').

\subsection{Models}

The models include the interaction between the three main independent variables: the household income, marital status and gender. Because the association between household income and time spent on housework can be non-linear, we also added the quadratic terms into interactions (see Table 2). 
Due to the non-normal distribution of the dependent variable, we have decided to employ negative binomial regression for the analysis, which is new in housework research. Although most housework research opts to use OLS regression in the analysis of the associations where the dependent variable is a time variable (Stewart, 2013), in this paper, we have ventured to use a new technique but also report that the results would not differ if OLS is used instead of the negative binomial regression. The graphs are produced with estimating the predicted margins on all levels of household income based on the results of the models.

\section{Results}

The separate estimates for Japan, USA, and Canada are used to analyze the effects of SES (measured in household income) on the time spent on routine housework, cooking and cleaning. Table 2 summarizes the estimates of the negative binomial regressions for each country, including the interaction effects. The results for the effects of the socioeconomic status on housework participation and its interaction effects with gender and marital status are similar in Canada and the US, however, the results for Japan are distinct.

Although the main factor explored in this paper that test the effects of the socioeconomic status is household income, we should also take into consideration that to some extent education also reflects one's SES. We find that the socioeconomic status of Japanese married women results in the patterns that are not expected under the assumption of Hypothesis 1. We find that against the expectations of the hypothesis, higher SES does not help Japanese women to reduce their involvement in housework, when controlled for education and other independent variables (see Table 2). We find that Japanese married women spend more time on routine housework with the increase in their household income. 
The results and marginal effects are discussed in more detail in the following section. Thus, the expectations of the negative association between SES and housework participation might only be applicable in the context of Western countries but not in Japan.

Moreover, the other variable that also can test the effects of SES, education has an opposite effect on women's participation in housework in Japan than it does in the US, even when controlled for household income (see Table 2). Thus, Japanese women with higher levels of education are expected to spend more time on routine housework than Japanese women with lower levels of education. The effects of education are significant in Japan and the US, and not significant in Canada, though they are in the expected direction (by the traditional housework theory) both in Canada and the US (see Table 2). However, in the models among women only in Table 3, the association of education with housework participation is on a statistically significant level for all three countries. Similar results were obtained in Kolpashnikova, Kan, and Shirakawa (2019a). On the other hand, supporting the results of other housework researchers, which showed that men increase their participation in housework with the increase in their education levels and other resources (Kolpashnikova, 2018), our findings confirm that Hypothesis 1 appears to hold among men (see Table 4), including in the case of Japanese men, ceteris paribus.

Overall, it is only among Japanese women that the association of household income and education with housework participation appears to go against the expectations of Hypothesis 1.

The effects of other control variables are similar for the three countries. Thus, individuals are likely to perform more housework on a weekend than on a weekday in all 
countries. Age seems to affect women's participation in housework in the way that they increase their participation to a certain age point and then start reducing it with age (negative quadratic association). Having children increases the involvement of women in housework in all three countries.

Table 2 Negative Binomial Regression Coefficients, Full Models for Japan, USA, and Canada

\begin{tabular}{|c|c|c|c|}
\hline & $\begin{array}{c}\text { Japan } \\
(\mathrm{N}=270619)\end{array}$ & $\begin{array}{c}\text { USA } \\
(\mathrm{N}=167637)\end{array}$ & $\begin{array}{c}\text { Canada } \\
(\mathrm{N}=48573)\end{array}$ \\
\hline Female & $\begin{array}{l}1.184^{* * *} \\
(0.094)\end{array}$ & $\begin{array}{l}0.759^{* * *} \\
(0.053)\end{array}$ & $\begin{array}{l}0.848^{* * *} \\
(0.075)\end{array}$ \\
\hline Married & $\begin{array}{c}-0.568^{* * *} \\
(0.103)\end{array}$ & $\begin{array}{l}-0.205^{* *} \\
(0.070)\end{array}$ & $\begin{array}{l}-0.230^{* *} \\
(0.086)\end{array}$ \\
\hline Female*Married & $\begin{array}{l}1.028^{* * *} \\
(0.111)\end{array}$ & $\begin{array}{l}0.717^{* * *} \\
(0.076)\end{array}$ & $\begin{array}{l}0.671^{* * *} \\
(0.096)\end{array}$ \\
\hline Income & $\begin{array}{c}-1.620^{* * *} \\
(0.333)\end{array}$ & $\begin{array}{l}-0.368 \\
(0.215)\end{array}$ & $\begin{array}{l}-0.260 \\
(0.249)\end{array}$ \\
\hline Female*Income & $\begin{array}{c}0.248 \\
(0.376)\end{array}$ & $\begin{array}{l}-0.537^{*} \\
(0.235)\end{array}$ & $\begin{array}{l}-0.788^{* *} \\
(0.299)\end{array}$ \\
\hline Married*Income & $\begin{array}{l}0.830^{*} \\
(0.387)\end{array}$ & $\begin{array}{c}0.487 \\
(0.253)\end{array}$ & $\begin{array}{c}0.257 \\
(0.292)\end{array}$ \\
\hline Female*Married*Income & $\begin{array}{l}1.268^{* *} \\
(0.428)\end{array}$ & $\begin{array}{l}-0.460 \\
(0.278)\end{array}$ & $\begin{array}{c}0.025 \\
(0.348)\end{array}$ \\
\hline Income*Income & $\begin{array}{l}0.731^{* *} \\
(0.254)\end{array}$ & $\begin{array}{c}0.075 \\
(0.168)\end{array}$ & $\begin{array}{l}-0.018 \\
(0.180)\end{array}$ \\
\hline Female*Income*Income & $\begin{array}{l}-0.195 \\
(0.290)\end{array}$ & $\begin{array}{c}0.252 \\
(0.183)\end{array}$ & $\begin{array}{c}0.361 \\
(0.233)\end{array}$ \\
\hline Married*Income*Income & $\begin{array}{l}-0.523 \\
(0.290)\end{array}$ & $\begin{array}{l}-0.170 \\
(0.184)\end{array}$ & $\begin{array}{c}0.069 \\
(0.204)\end{array}$ \\
\hline Female*Married*Income*Income & $\begin{array}{l}-0.501 \\
(0.324)\end{array}$ & $\begin{array}{c}0.181 \\
(0.202)\end{array}$ & $\begin{array}{l}-0.201 \\
(0.259)\end{array}$ \\
\hline Education in Years & $\begin{array}{l}0.026^{* * *} \\
(0.005)\end{array}$ & $\begin{array}{l}-0.007^{* *} \\
(0.002)\end{array}$ & $\begin{array}{l}-0.001 \\
(0.003)\end{array}$ \\
\hline Children & $\begin{array}{l}0.134^{* * *} \\
(0.023)\end{array}$ & $\begin{array}{l}0.196^{* * *} \\
(0.017)\end{array}$ & $\begin{array}{l}0.266^{* * *} \\
(0.017)\end{array}$ \\
\hline Weekday & $\begin{array}{c}-0.253^{* * *} \\
(0.020)\end{array}$ & $\begin{array}{c}-0.272^{* * *} \\
(0.012)\end{array}$ & $\begin{array}{c}-0.289^{* * *} \\
(0.017)\end{array}$ \\
\hline Age & $\begin{array}{l}0.072^{* * *} \\
(0.003)\end{array}$ & $\begin{array}{l}0.050^{* * *} \\
(0.002)\end{array}$ & $\begin{array}{l}0.045^{* * *} \\
(0.003)\end{array}$ \\
\hline Age*Age & $\begin{array}{c}-0.000^{* * *} \\
(0.000)\end{array}$ & $\begin{array}{c}-0.000^{* * *} \\
(0.000)\end{array}$ & $\begin{array}{c}-0.000^{* * *} \\
(0.000)\end{array}$ \\
\hline Constant & $\begin{array}{l}0.831^{* * *} \\
(0.124)\end{array}$ & $\begin{array}{l}2.702^{* * * *} \\
(0.076)\end{array}$ & $\begin{array}{l}2.802^{* * *} \\
(0.096)\end{array}$ \\
\hline
\end{tabular}

Robust standard errors in parentheses; ${ }^{*} p<0.05,{ }^{* *} p<0.01,{ }^{* * *} p<0.001$ 
Table 3 Negative Binomial Regression Coefficients, Japanese, American, and Canadian Women

\begin{tabular}{lccc}
\hline & $\begin{array}{c}\text { Japanese Women } \\
(\mathrm{N}=141886)\end{array}$ & $\begin{array}{c}\text { American Women } \\
(\mathrm{N}=94086)\end{array}$ & $\begin{array}{c}\text { Canadian Women } \\
(\mathrm{N}=26283)\end{array}$ \\
\hline Married & $0.319^{* * * *}$ & $0.485^{* * * *}$ & $0.415^{* * *}$ \\
& $(0.036)$ & $(0.030)$ & $(0.042)$ \\
Income & $-1.302^{* * * *}$ & $-0.736^{* * *}$ & $-0.856^{* * *}$ \\
& $(0.153)$ & $(0.099)$ & $(0.174)$ \\
Married*Income & $1.434^{* * *}$ & 0.006 & 0.219 \\
& $(0.162)$ & $(0.115)$ & $(0.189)$ \\
Income*Income & $0.543^{* * *}$ & $0.263^{* * *}$ & 0.249 \\
& $(0.121)$ & $(0.075)$ & $(0.150)$ \\
Married*Income*Income & $-0.745^{* * *}$ & 0.023 & -0.076 \\
& $(0.126)$ & $(0.084)$ & $(0.160)$ \\
Education in Years & $0.032^{* * * *}$ & $-0.028^{* * *}$ & $-0.026^{* * *}$ \\
& $(0.004)$ & $(0.002)$ & $(0.003)$ \\
Children & $0.416^{* * *}$ & $0.352^{* * * *}$ & $0.370^{* * *}$ \\
& $(0.013)$ & $(0.016)$ & $(0.018)$ \\
Weekday & $-0.029^{* * *}$ & $-0.206^{* * *}$ & $-0.175^{* * *}$ \\
Age & $(0.013)$ & $(0.011)$ & $(0.017)$ \\
Age*Age & $0.127^{* * *}$ & $0.055^{* * *}$ & $0.043^{* * *}$ \\
& $(0.003)$ & $(0.002)$ & $(0.003)$ \\
Constant & $-0.001^{* * *}$ & $-0.000^{* * *}$ & $-0.001^{* * *}$ \\
& $(0.000)$ & $(0.000)$ & $(0.000)$ \\
\hline
\end{tabular}

Robust standard errors in parentheses; ${ }^{*} p<0.05,{ }^{* *} p<0.01,{ }^{* * *} p<0.001$

Table 4 Negative Binomial Regression Coefficients, Japanese, American, and Canadian Men

\begin{tabular}{lccc}
\hline & $\begin{array}{c}\text { Japanese Men } \\
(\mathrm{N}=128733)\end{array}$ & $\begin{array}{c}\text { American Men } \\
(\mathrm{N}=73551)\end{array}$ & $\begin{array}{c}\text { Canadian Men } \\
(\mathrm{N}=22290)\end{array}$ \\
\hline \hline Married & $-0.763^{* * *}$ & -0.130 & $-0.200^{*}$ \\
& $(0.116)$ & $(0.069)$ & $(0.085)$ \\
Income & -1.692 & $-0.446^{*}$ & -0.358 \\
& $(0.343)$ & $(0.210)$ & $(0.250)$ \\
Married*Income & $1.607^{* * *}$ & 0.448 & 0.269 \\
& $(0.421)$ & $(0.246)$ & $(0.290)$ \\
Income*Income & 0.720 & 0.084 & 0.025 \\
& $(0.259)$ & $(0.161)$ & $(0.181)$ \\
Married*Income*Income & $-0.856^{* *}$ & -0.150 & 0.049 \\
Education in Years & $(0.310)$ & $(0.178)$ & $(0.204)$ \\
& $0.024^{* *}$ & $0.015^{* * *}$ & $0.019^{* * *}$ \\
Children & $(0.008)$ & $(0.004)$ & $(0.005)$ \\
& -0.068 & 0.036 & $0.157^{* * *}$ \\
Weekday & $(0.051)$ & $(0.029)$ & $(0.030)$ \\
& $-0.558^{* * *}$ & $-0.349^{* * * *}$ & $-0.401^{* * *}$ \\
Age & $(0.038)$ & $(0.020)$ & $(0.028)$ \\
& $0.022^{* *}$ & $0.045^{* * * *}$ & $0.047^{* * *}$ \\
Age*Age & $(0.007)$ & $(0.007)$ & $(0.005)$ \\
Constant & $0.000^{* *}$ & $-0.000^{* * *}$ & $-0.000^{* * *}$ \\
& $(0.000)$ & $(0.000)$ & $(0.000)$ \\
\hline
\end{tabular}

Robust standard errors in parentheses; ${ }^{*} p<0.05,{ }^{* *} p<0.01,{ }^{* * *} p<0.001$ 
We can conclude our results therefore in the following way: contrary to the arguments proposed by the housework theory regarding the association between SES and housework participation, the results in Japan among married women seems to be contrary to expectations and hold for the North American countries. This confirms prior research on the ‘marriage penalty’ among Japanese women (Kolpashnikova, Kan, \& Shirakawa, 2019b).

\subsection{Marginal Effects Analysis}

Figure 1 summarizes the results of Table 2 and the effects of the independent variable (household income on the $\mathrm{x}$-axis) on the participation in housework (y-axis) for married and non-married women and men for two countries, Japan and the US. The results for Canada were similar to those in the US, so they were omitted in this section as redundant.
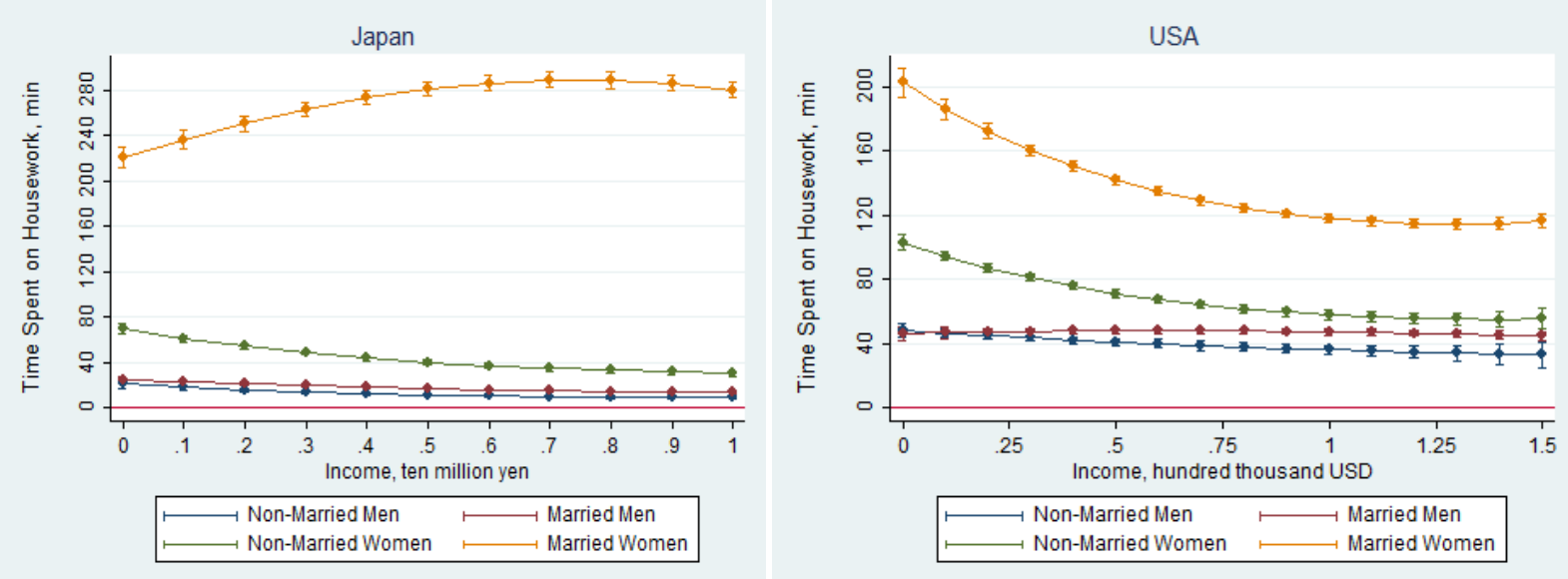

Figure 1 Marginal Effects of Levels of Household Income on Time Spent on Housework in Japan and USA

The upper curve on the left panel of Figure 1 represents the association between household income and participation in routine housework for married Japanese women. It shows that married Japanese women mostly increase their involvement in routine housework with the increase in their socioeconomic status. This is unlike non-married Japanese women (the curve below the upper curve on the left panel of Figure 1), as well as married and non-married Japanese men (two lower curves on the left panel). Non-married 
Japanese women decrease their housework time with the increase of their household income, controlled for age, education and other control variables, as expected under Hypothesis 1.

Unlike married Japanese women, married American women decrease their participation in housework with the increase in their socioeconomic status (see the upper curve of the right panel of Figure 1). This might suggest that they outsource a part of their housework responsibilities to hired help or constrained in the time to be able to perform more housework as their Japanese counterparts. The pattern among married American women is similar to the pattern among non-married American women (see the right panel of Figure 1), although married women on average are expected to perform more housework than nonmarried women, just like in Japan. For both Japanese and American men, their participation in routine housework does not change substantially with marriage or household income level. But there is also a pattern that distinguishes married American men from their Japanese counterparts. Married American men spend a little more time on housework than non-married men with an increase in their SES (Kolpashnikova, 2018), especially among American men with even higher socioeconomic status.

\section{Conclusions}

The resource-based approaches in housework theory were developed based on the results in the global north. However, often the ways how the resource-based factors, including those measuring socioeconomic status, work in different cultural contexts is underplayed. The results of the present study show that even though SES provides Japanese women with an ability to outsource most of the housework or be more engaged in the labor market, the married women are unlikely to do so because of the structural barriers that they face, whereas non-married wealthier women are almost as likely to reduce their time spent 
on housework as married and non-married Japanese men. Only in Canada and the US

(within the present analysis), SES is associated with a reduction in housework time among married women.

Future housework research could benefit from developing theoretical frameworks that take into consideration contextual and cultural differences.

\section{References}

Alwin, D. F., \& McCammon, R. J. (2004). Generations, cohorts, and social change. New York, NY: Springer.

Bianchi, S. M., Robinson, J. P., \& Milkie, M. A. (2006). Changing Rhythms of American Family Life. New York, NY: Russell Sage Foundation.

Bureau of Labor Statistics. (2018). American Time Use Survey.

Coltrane, S. (2000). Research on Household Labor: Modeling and Measuring the Social Embeddedness of Routine Family Work. Journal of Marriage and Family, 62(4), 1208-1233.

Gimenez-Nadal, J. I., \& Sevilla, A. (2012). Trends in time allocation: A cross-country analysis. European Economic Review, 56(6), 1338-1359.

Guppy, N., Sakumoto, L., \& Wilkes, R. (2019). Social Change and the Gendered Division of Household Labor in Canada. Canadian Review of Sociology/Revue canadienne de sociologie, 56(2), 178-203.

Hochschild, A. R., \& Machung, A. (1989). The Second Shift. The Second Shift, 95-158. doi:10.2307/3340976

Hofferth, S. L., Flood, S. M., \& Sobek, M. (2016). American Time Use Survey Data Extract Builder.

Hook, J. L. (2017). Women's Housework: New Tests of Time and Money. Journal of Marriage and Family, 79(1), 179-198.

Kan, M. Y., Sullivan, O., \& Gershuny, J. (2011). Gender convergence in domestic work: Discerning the effects of interactional and institutional barriers from large-scale data. Sociology, 45(2), 234-251. doi:10.1177/0038038510394014

Kolpashnikova, K. (2016). Housework in Canada: uneven convergence of the gender gap in domestic tasks, 1986-2010. University of British Columbia, Vancouver, BC.

Kolpashnikova, K. (2018). American Househusbands: New Time Use Evidence of Gender Display, 2003-2016. Social Indicators Research, 140(3), 1259-1277. doi:10.1007/s11205-017-1813-z

Kolpashnikova, K., Kan, M. Y., \& Shirakawa, K. (2019a). Marriage and Housework: Analyzing the Effects of Education Using the 2011 and 2016 Japanese Survey on Time Use and Leisure Activities. IER Discussion Paper Series, 696.

Kolpashnikova, K., Kan, M. Y., \& Shirakawa, K. (2019b). Marriage Penalty: Unconditional Quantile Regression of Housework Participation in Japan. IER Discussion Paper Series, 695. 
Marshall, K. (1986). Converging gender roles. Women, 1-13.

Marshall, K. (2011). Generational change in paid and unpaid work. Canadian Social Trends, $11,11-24$.

Stewart, J. (2013). Tobit or not tobit? Journal of Economic and Social Measurement, 38. 